\title{
PEMBERDAYAAN PEREMPUAN DALAM PROGRAM BUMDES DESA BELO
}

\author{
Zuhrah, Husnatul Mahmudah, Juhriati. \\ Sekolah Tinggi Ilmu Hukum Muhammadiyah Bima \\ Institut Agama Islam Muhammadiyah Bima \\ Jl. Anggrek No. 16 Ranggo Na'e Kota Bima \\ zhoemachy@gmail.com, arraynez@gmail.com, \\ juhriatiburhan@gmail.com
}

\section{Abstrak}

Desa yang merupakan kesatuan wilayah yang berwenang untuk mengatur dan mengurus urusan pemerintahan, kepentingan masyarakat setempat berdasarkan prakarsa masyarakat, hak asal usul, dan/atau hak tradisional yang diakui dan dihormati dalam sistem pemerintahan Negara Kesatuan Republik Indonesia perlu dilindungi dan diberdayakan agar menjadi kuat, maju, mandiri, demokratis sehingga dapat menciptakan landasan yang kuat dalam melaksanakan pemerintahan dan pembangunan menuju masyarakat yang adil, makmur dan sejahtera.

Dalam konteks kekinian secara umum di Indonesia, bahwa angka kemiskinan masih terbilang tinggi. Hal ini memicu pemerintah untuk berinovasi dalam membuat program yang bertujuan untuk memberdayakan masyarakat. Program tersebut adalah program pemerintah pusat, tetapi akan diperpanjangtangankan oleh pemerintah desa agar berjalan efektif dan efisien. Program pemerintah tersebut adalah program BUMDes yakni badan usaha yang seluruh atau sebagian besar modalnya dimiliki oleh desa melalui penyertaan secara langsung yang berasal dari 
kekayaan Desa yang dipisahkan guna mengelola asset, jasa pelayanan, dan usaha lainnya untuk sebesar-besarnya kesejahteraan masyarakat.

Program BUMDes pertama kali dicanangkan oleh pemerintah sejak tahun 2014 bertepatan dengan lahirnya Undang-undang Nomor 6 Tahun 2014 Tentang Desa. Program BUMDes ini diharapkan menjadi program unggulan setiap Desa karena sifatnya yang massif untuk menyejahterakan masyarakat. Akan tetapi, program BUMDes ini masih dirasa belum efektif oleh sebagian masyarakat di Desa Belo. Sehingga peneliti ingin menelusuri sejauhmana efektifitas perjalanan program BUMDes di Desa Belo Kecamatan Palibelo Kabupaten Bima dalam memberdayakan kaum perempuan khususnya.

\section{Keywords: BUMDes, Pemberdayaan, Perempuan.}

\section{Latar Belakang}

Desa adalah desa dan desa adat atau yang disebut dengan nama lain, selanjutnya disebut desa, adalah kesatuan wilayah yang berwenang untuk mengatur dan mengurus urusan pemerintahan, kepentingan masyarakat setempat berdasarkan prakarsa masyarakat, hak asal usul, dan/atau hak tradisional yang diakui dan dihormati dalam system pemerintahan Negara Kesatuan Republik Indonesia. ${ }^{1}$

Dalam perjalanan ketatanegaraan Republik Indonesia, Desa telah berkembang dalam berbagai bentuk sehingga perlu dilindungi dan diberdayakan agar menjadi kuat, maju, mandiri, demokratis sehingga dapat menciptakan landasan yang kuat

1 Ketentuan Umum Undang-undang Republik Indonesia nomor 6 Tahun 2014. 
dalam melaksanakan pemerintahan dan pembangunan menuju masyarakat yang adil, makmur dan sejahtera. ${ }^{2}$

Masyarakat desa dengan latar belakang yang heterogen memiliki tujuan hidup yang sama, yakni menuju masyarakat yang adil, makmur dan sejahtera. Akan tetapi, dari latar belakang setiap keluarga baik dari segi pendidikan, keterampilan tidaklah sama. Sehingga, dengan status sebagai masyarakat desa yang belum terakomodir dalam dunia kerja menjadi tanggung jawab pemerintah desa untuk melakukan pemberdayaan melalui program-program pemberdayaan.

Masyarakat yang diberikan pemberdayaan tidak hanya kaum laki-laki, tetapi juga kaum perempuan. Dimana perempuan yang kehilangan suami sebagai kepala keluarga atau tulang punggung keluarga, atau suami masih ada tetapi dalam keadaan tidak mampu memberdayakan keluarga. Dalam hal ini, perempuan menjadi orang tua tunggal atau berganti peran sebagai kepala keluarga sekaligus sebagai tulang punggung keluarga. Sehingga Negara secara umum atau pemerintah Desa sebagai perpanjangan tangan pemerintah pusat berkewajiban memberikan kesejahteraan kepada masyarakatnya secara adil dan merata.

Pemberdayaan perempuan adalah suatu proses kesadaran dan pembentukan kapasitas (capacity building) terhadap partisipasi yang lebih besar, kekuasaan dan pengawasaan pembuatan keputusan yang lebih besar dan tindakan transformasi agar menghasilkan persamaan derajat yang lebih besar antara perempuan dan laki-laki. ${ }^{3}$

Kementerian Desa, Pembangunan Daerah Tertinggal dan Transmigrasi sejak dilahirkannya Undang-undang Nomor 6

${ }^{2}$ Ibid.

3 Onny S. Prijono dan A.M.W. Pranarka, Pemberdayaan, Konsep, Kebijakan dan Implementasi, (Jakarta: CSIS, t.t).

Sangaji Jurnal Pemikiran Syariah dan Hukum 
Tahun 2014 tentang Desa mencetuskan salah satu program yang bertujuan untuk melakukan pemberdayaan masyarakat desa yakni melalui Badan Usaha Milik Desa (BUMDes).

Badan usaha milik desa adalah badan usaha yang seluruh atau sebagian besar modalnya dimiliki oleh desa melalui penyertaan secara langsung yang berasal dari kekayaan Desa yang dipisahkan guna mengelola asset, jasa pelayanan, dan usaha lainnya untuk sebesar-besarnya kesejahteraan masyarakat. ${ }^{4}$

Adapun program yang dicanangkan oleh BUMDes beragam bentuk. Misalnya BUMDes di Desa Belo Kecamatan Palibelo Kabupaten Bima memiliki program terpisah untuk kaum laki-laki dan perempuan. Untuk kaum laki-laki dicanangkan program pada bidang pertanian, perkebunan dan perikanan. Sedangkan program untuk kaum perempuan fokus pada pengolahan hasil perikanan. Desa Belo adalah salah satu wilayah di Kabupaten Bima sebagai penghasil garam dan ikan Bandeng terbanyak sebagai penyuplai komoditi ikan untuk wilayah kota maupun kabupaten Bima.

Dalam penelitian ini, tujuan yang ingin dicapai adalah mengetahui program pengolahan hasil yang seperti apa yang dijalankan oleh BUMDes Desa Belo Kecamatan Palibelo Kabupaten Bima serta bagaimana hasil dari pemberdayaan terhadap perempuan atas program tersebut.

\section{Tinjauan Pustaka}

Yeni Fajarwati meneliti tentang Implementasi Poragram BUMDes di Desa Pagedangan Kecamatan Pagedangan Kabupaten Tangerang pada tahun 2016. Hasil penelitian tersebut menunjukkan bahwa implementasi program BUMDes secara umum sudah berjalan dengan baik. Akan tetapi dari segi perencanaan keuangan dan program belum terkelola dengan baik

${ }^{4}$ Ibid. 
sehingga program BUMDes belum sepenuhnya berjalan dengan optimal karena ada beberapa yang harus diperbaiki seperti kurangnya sumber daya manusia dan finansial serta lemahnya sosialisasi dan minimnya koordinasi. ${ }^{5}$

Peranan Badan Usaha Milik Desa (BUMDes) Dalam Peningkatan Pendapatan Asli Desa yang ditulis Ade Eka Kurniawan dengan Lokus di Desa Lanjut Kecamatan Singkep Pesisir Kabupaten Lingga pada tahun 2015. Penelitian tersebut menelusuri peranan BUMDes Desa Lanjut dengan hasil bahwa BUMDes telah menunjukkan perannya dalam meningkatkan pendapatan asli Desa sebagai fasilitator, mediator, motivator, dinamisator sudah mengalami peningkatan. Akan tetapi, peningkatan tersebut tidak cukup signifikan, hanya sekitar tiga jutaan. ${ }^{6}$

Selanjutnya adalah Muhammad Yasser Arafat meneliti tentang Badan Usaha Milik Desa Dan Pemberdayaan Ekonomi Masyarakat Desa (Studi Pada BUMDes Tirta Mandiri Desa Ponggok Kecamatan Polanharjo Kabupaten Klaten). Teori yang digunakan dalam penelitian ini adalah teori Organisasi Stephen P. Robbins (1994) yang mengkaji struktur, fungsi dan performansi organisasi beserta perilaku kelompok dan individu didalamnya dalam mencapai tujuan yang luas dan rumit. Penelitian ini menggunakan metode penelitian kualitatif deskriptif analisis yaitu menganalisis data dengan menjelaskan dan menafsirkan data atau informasi dari hasil penelitian. Pengumpulan data dalam penelitian ini menggunakan observasi yaitu, untuk melihat kondisi masyarakat dan BUMDes di Desa Ponggok, wawancara

5 Yeni Fajarwati, 2016, "Implementasi Program Badan Usaha Milik Desa (BUMDes) di Desa Pagedangan Kecamatan Pagedangan Kabupaten Tangerang", Skripsi Tidak Terbit.

6 Ade Eka Kurniawan, 2015, "Peranan Badan Usaha Milik Desa (BUMDes) Dalam Peningkatan Pendapatan Asli Desa", Skripsi Tidak Terbit

Sangaji Jurnal Pemikiran Syariah dan Hukum 
dilakukan untuk mendapatkan informasi dari masyarakat dan pengelola BUMDes dengan tanya jawab secara langsung, dan dokumentasi sebagai perolehan data berupa tulisan maupun gambar untuk menambah informasi. Analisis data melalui tahapan reduksi data, Model Data (Data Display) dan Penarikan/Verifikasi Kesimpulan.

Hasil penelitian yang telah dilakukan, tentang peran BUMDes Tirta Mandiri sangat berpengaruh untuk meningkatkan kesejahteraan ekonomi masyarakat Desa Ponggok. Hal ini dibuktikan dari terciptanya lapangan pekerjaan baru, unit-unit usaha yang dijalankan berkembang pesat dan warga diberi kesempatan untuk membuka usaha dengan difasilitasi oleh BUMDes. Disamping itu pemerintah juga turut mendapatkan manfaatnya berupa peningkatan pendapatan asli desa (PAD) yang sangat signifikan setelah adanya BUMDes. Program bantuan sosial juga turut membantu masyarakat menjadi lebih sejahtera. Adapun program bantuan sosial yang digulirkan antara Pemerintah Desa dengan BUMDes Tirta Mandiri antara lain satu rumah satu sarjana, bantuan uang untuk pendududk lansia, program renovasi rumah yang tidak layak huni, program listrik gratis bagi warga yang rumahnya belum teraliri listrik dan biaya premi BPJS Kesehatan yang ditanggung oleh Pemerintah Desa. ${ }^{7}$

Dilihat dari beberapa penelitian terkait dengan program BUMDes lima tahun terakhir belum ada yang mengarah pada pemberdayaan perempuan, hanya terbatas pada implementasi BUMDes terhadap kesejahteraan masyarakat maupun peranan BUMDes terhadap peningkatan pendapatan asli desa. Sehingga penelitian tentang Pemberdayaan Perempuan Pada Program BUMDes ini menjadi wacana perdana yang sifatnya feminis.

7 Muhammad Yasser Arafat, 2018, “Badan Usaha Milik Desa Dan Pemberdayaan Ekonomi Masyarakat Desa (Studi Pada BUMDes Tirta Mandiri Desa Ponggok Kecamatan Polanharjo Kabupaten Klaten)" Skripsi Tidak Terbit 
Dalam artian bahwa program pemerintah yang telah dicanangkan selama ini masih mengenyampingkan peran perempuan dalam pengembangan ekonomi rakyat meski masih dalam tataran kekeluargaan.

\section{Program BUMDes Untuk Masyarakat}

Badan Usaha Milik Desa (BUM Desa/ BUMDes) menjadi salah satu program prioritas Kementerian Desa, Pembangunan Daerah Tertinggal dan Transmigrasi (Kemendes PDTT) Tahun 2017 di samping 3 program lainnya, yakni One Village One Product (Satu Desa Satu Produk); Embung Desa; dan Sarana Olahraga. Melalui BUMDes, masyarakat desa didorong untuk mengelola ekonomi secara otonom.

Berdirinya BUMDes pada setiap desa harus berdasarkan dari hasil musyawarah desa. Unsur musyawarah desa terdiri dari tokoh adat, tokoh agama, tokoh pendidikan, tokoh masyarakat, perwakilan kelompok perempuan, perwakilan tani dan seluruh unsur masyarakat desa lainnya. Pendirian BUMDes seyogyanya sesuai dengan kebutuhan, kondisi ekonomi dan sosial budaya masyarakat.

Salah satu hal penting yang harus menjadi pertimbangan dalam mendirikan BUMDes, bahwa jenis usaha yang dipilih BUMDes tidak diperbolehkan mengancam kegiatan ekonomi masyarakat desa. Kehadiran BUMDes harus mampu menampung, mengkonsolidasi, dan mewadahi kegiatan usaha ekonomi desa.

Desa saat ini memiliki berbagai permasalahan ekonomi seperti rendahnya penguasaan lahan dan skala usaha yang relatif kecil bahkan cenderung subsisten; akses pendanaan yang terbatas dan cenderung berpola 'ijon'; kurang memiliki akses pasar dan nilai tawar yang rendah; kurang memiliki pengetahuan mengenai cara produksi yang baik; sarana dan prasarana belum mendukung input produksi, proses produksi, dan pasca 
produksi. Hadirnya BUMDes dalam hal ini menjadi jawaban atas permasalahan-permasalahan tersebut, yang diharapkan mampu menjadi motor penggerak ekonomi desa.

Di sisi lain, dana desa sebagai salah satu program utama pemerintah yang menggelontorkan dana langsung ke desa, adalah stimulus agar kemudian desa mampu berkembang secara mandiri. Salah satu upaya yang dilakukan dalam hal ini adalah dengan menggeliatkan BUMDes. Sehingga selain untuk pembangunan sarana dan prasarana desa, sebagian dana desa juga dapat digunakan untuk mendirikan BUMDes.

Program BUMDes sendiri merupakan amanat dari UU No 6 Tahun 2014 tentang Desa, seperti disebutkan (Pasal 87) bahwa: (1) Desa dapat mendirikan Badan Usaha Milik Desa yang disebut BUM Desa; (2) BUM Desa dikelola dengan semangat kekeluargaan dan kegotongroyongan; dan (3) BUM Desa dapat menjalankan usaha di bidang ekonomi dan/atau pelayanan umum sesuai dengan ketentuan peraturan perundang-undangan. Selanjutnya terkait pengelolaan BUMDes, diatur dalam Peraturan Menteri Desa, Pembangunan Daerah Tertinggal dan Transmigrasi RI Nomor 4 Tahun 2015 tentang Pendirian, Pengurusan dan Pengelolaan, dan pembubaran Badan Usaha Milik Desa.

\section{Pemberdayaan Perempuan dalam Pandangan Masyarakat}

Istilah perempuan secara etimologi mengandung arti Orang (manusia) yang mempunyai puki, dapat menstruasi, hamil, melahirkan anak dan menyusui. ${ }^{8}$ Perempuan dalam keluarga adalah bagian terpenting, meski kedudukannya selalu ditempatkan pada tugas domestic. Dimana perempuan dianggap sebagai second class yakni ibu rumah tangga yang hanya

${ }^{8}$ Saptosi Ismiati, Kekerasan Dalam Rumah Tangga (KDRT) dan Hak Asasi Manusia (HAM) (Sebuah kajian Yuridis), Yogyakarta: Deepublish Publisher, 2020, 11. 
bertugas di dalam rumah saja. Tetapi kini, perempuan sudah beranjak pada kesetaraan dimana perempuan dan laki-laki memiliki kedudukan yang sama. Sebagai contoh, perempuan masa kini sudah berperan aktif dalam pembangunan Negara secara umum meski tugasnya di wilayah masing-masing. Peran tersebut meliputi aspek pendidikan, social ekonomi, hukum, politik dan lain-lain. Hal tersebut juga dipengaruhi oleh tuntutan bangsa atas nama masyarakat global bahwa kemajuan suatu bangsa ditentukan bagaimana bangsa tersebut peduli dan memberi akses yang luas bagi perempuan untuk beraktifitas dalam ranah publik. ${ }^{9}$

Peran-peran dalam ranah publik tersebut merupakan bagian dari pemberdayaan perempuan oleh masyarakat yang semula perempuan hanya berperan dalam rumah. Akan tetapi, seiring perkembangan ilmu dan pemikiran manusia, maka perempuan telah dianggap sebagai mitra laki-laki dalam segala hal yang mampu menjadi pilar pengganti laki-laki baik dalam kehidupan rumah tangga maupun bermasyarakat secara umum. Ini merupakan sebuah kemajuan paradigma masyarakat terhadap perempuan.

Pemberdayaan perempuan adalah suatu proses kesadaran dan pembentukan kapasitas (capacity building) terhadap partisipasi yang lebih besar, kekuasaan dan pengawasan pembuatan keputusan yang lebih besar dan tindakan transformasi agar menghasilkan persamaan derajat yang lebih besar antara perempuan dan laki-laki. ${ }^{10}$

Pemberdayaan merupakan transformasi hubungan kekuasaan antara laki-laki dan perempuan pada empat level yang

9 Indah Ahdiah, "Peran-Peran Perempuan Dalam Mayarakat" Jurnal Academica FISIP Untad Vol.05 Nomor 02 Oktober 2013, 1085.

10 Prijono, O.S., dan Pranarka, A.M.W . 1996. Pemberdayaan: Konsep, Kebijakan dan Implementasi. Jakarta: CSIS, hal.75

Sangaji Jurnal Pemikiran Syariah dan Hukum 
berbeda, yakni keluarga, masyarakat, pasar dan negara. Posisi perempuan akan membaik hanya ketika perempuan dapat mandiri dan mampu menguasai atas keputusan-keputusan yang berkaitan dengan kehidupannya.

Pemberdayaan perempuan menjadi strategi penting dalam meningkatkan peran perempuan dalam meningkatkan potensi diri agar lebih mampu mandiri dan berkarya. Kesadaran mengenai peran perempuan mulai berkembang yang diwujudkan dalam pendekatan program perempuan dalam pembangunan. Hal ini didasarkan pada satu pemikiran mengenai perlunya kemandirian bagi kaum perempuan, supaya pembangunan dapat dirasakan oleh semua pihak. Karena perempuan merupakan sumber daya manusia yang sangat berharga sehingga posisinya diikut sertakan dalam pembangunan. ${ }^{11}$

Pemberdayaan perempuan dilakukan untuk menunjang dan mempercepat tercapainya kualitas hidup dan mitra kesejajaran antara laki-laki dan perempuan yang bergerak dalam seluruh bidang atau sektor. Keberhasilan pemberdayaan perempuan dapat dilihat adanya indikator-indikator sebagai berikut: ${ }^{12}$

1. Adanya sarana yang memadai guna mendukung perempuan untuk menempuh pendidikan semaksimal mungkin;

2. Adanya peningkatan partisipasi dan semangat kaum perempuan untuk berusaha memperoleh dan mendapatkan pendidikan dan pengajaran bagi diri mereka;

3. Meningkatnya jumlah perempuan mencapai jenjang pendidikan tinggi, sehingga dengan demikian, perempuan

11 Zakiyah. 2010. Pemberdayaan Perempuan oleh Lajnah Wanita.

Jurnal Pengkajian Masalah Sosial Keagamaan, No.XVII. hal.61

12 Suharto, Edi. 2003. Pembangunan Kebijakan dan Kesejahteraan

Sosial. (Bandung: Mizan, 2003) 
mempunyai peluang semakin besar dalam mengembangkan karier sebagaimana halnya laki-laki

4. Adanya peningkatan jumlah perempuan dalam lembaga legislatif, eksekutif dan pemerintahan;

5. Peningkatan keterlibatan aktivis perempuan dalam kampanye pemberdayaan pendidikan terhadap perempuan.

Pemberdayaan perempuan merupakan cara strategis untuk meningkatkan potensi perempuan dan meningkatkan peran perempuan baik di domain publik maupun domestik. Menurut Zakiyah, ${ }^{13}$ pemberdayaan perempuan dapat dilakukan dengan strategi sebagai berikut:

1. Membongkar mitos kaum perempuan sebagai pelengkap dalam rumah tangga. Pada zaman dahulu, muncul anggapan yang kuat dalam masyarakat bahwa kaum perempuan adalah konco wingking (teman di belakang) bagi suami serta anggapan warga nunut neraka katut (ke surga ikut, ke neraka terbawa). Kata nunut dan katut dalam bahasa Jawa berkonotasi pasif dan tidak memiliki inisiatif, sehingga nasibnya sangat tergantung kepada suami;

2. Memberi beragam keterampilan bagi kaum perempuan. Strategi ini bertujuan agar kaum perempuan juga dapat produktif dan tidak menggantungkan nasibnya terhadap kaum laki-laki. Berbagai keterampilan bisa diajarkan, misalnya; ketrampilan menjahit, menyulam serta berwirausaha dengan membuat kain batik dan berbagai jenis makanan;

3. Memberikan kesempatan seluas-luasnya terhadap kaum perempuan untuk bisa mengikuti atau menempuh pendidikan seluas mungkin. Hal ini diperlukan mengingat

${ }^{13}$ Zakiyah. 2010. Pemberdayaan Perempuan oleh Lajnah Wanita...,

Sangaji Jurnal Pemikiran Syariah dan Hukum 
masih menguatnya paradigma masyarakat bahwa setinggitinggi pendidikan perempuan pada akhirnya nanti akan kembali ke dapur. Inilah yang mengakibatkan masih rendahnya (sebagian besar) pendidikan bagi perempuan.

Menurut Nugroho, ${ }^{14}$ terdapat beberapa program yang dapat ditawarkan untuk pemberdayaan perempuan, yaitu:

1. Penguatan organisasi kelompok perempuan di segala tingkat mulai dari kampung hingga nasional. Seperti misalnya PKK (Pembinaan Kesejahteraan Keluarga), perkumpulan koperasi maupun yayasan sosial. Penguatan kelembagaan ditujukan untuk meningkatkan kemampuan lembaga agar dapat berperan aktif sebagai perencana, pelaksana, maupun pengontrol;

2. Peningkatan fungsi dan peran organisasi perempuan dalam pemasaran sosial program-program pemberdayaan. Hal ini penting mengingat selama ini program pemberdayaan yang ada, kurang disosialisasikan dan kurang melibatkan peran masyarakat;

3. Pelibatan kelompok perempuan dalam perencanaan, pelaksanaan dan monitoring semua program pembangunan yang ada. Keterlibatan perempuan meliputi program pembangunan fisik, penguatan ekonomi, dan peningkatan kualitas sumber daya manusia;

4. Peningkatan kemampuan kepemimpinan perempuan, agar mempunyai posisi tawar yang setara serta memiliki akses dan peluang untuk terlibat dalam pembangunan;

5. Peningkatan kemampuan anggota kelompok perempuan dalam bidang usaha (skala industri kecil/rumah tangga hingga skala industri besar) dengan berbagai keterampilan

14 Nugroho. 2008. Gender dan Administrasi Publik Studi tentang Kualitas Kesetaraan dalam Administrasi Publik Indonesia Pasca Reformasi 19982002. Yogyakarta: Pustaka Pelajar 
yang menunjang seperti kemampuan produksi, kemampuan manajemen usaha serta kemampuan untuk mengakses kredit dan pemasaran yang lebih luas.

\section{Pemberdayaan Perempuan Dalam Program BUMDes Desa Belo}

Sebagaimana yang telah diuraikan di atas, bahwa program BUMDes di daerah lain belum ada yang mengarah kepada pemberdayaan perempuan. Desa Belo merupakan salah satu desa yang ada di kecamatan Palibelo Kabupaten Bima yang saat ini juga menjalankan program dan mendirikan Badan Usaha Milik Desa sebagaimana yang telah diamanatkan Undangundang No 6 Tahun 2014 tentang Desa.

BUMDes Desa Belo awal didirikan pada tahun 2017 yang berkantor di sekitar Bandar Udara Sultan Muhammad Salahuddin pda gedung yang dipinjam pakai dari Pemerintah Daerah Kabupaten Bima dengan modal awal dari pemerintah Desa yang dananya berasal dari APBDes sebesar sepuluh juta rupiah. Pengelolaan dana tersebut bersifat dana sharing dari pemerintah desa untuk masyarakat dengan metode sebagai modal jualan bakulan masyarakat. Akan tetapi, atas kelalaian masyarakat yang diberi pinjaman modal tersebut sehingga pada tahun 2018 dana APBDes tidak menganggarkan untuk BUMDes. Pada tahun 2019 Pemerintah Desa kembali mengucurkan dana APBDes untuk BUMDes sebesar Rp. 50.000.000,- dengan kepengurusan baru yang di SK kan oleh Kepala Desa.

Dari hasil wawancara dengan pengurus BUMDes Desa Belo bahwa BUMDes merupakan program pemerintah dalam rangka meningkatkan pemberdayaan kepada masyarakat. Baik laki-laki maupun perempuan diberi kesempatan yang sama. Akan tetapi, yang sangat menonjol adalah para ibu-ibu atau perempuan dalam menjemput program BUMDes tersebut. Semula para perempuan di Desa Belo hanya bertugas di rumah atau hanya sebatas menjadi ibu rumah tangga yang tidak 
produktif yang artinya hanya menjalankan tugas domestik. Setelah adanya BUMDes, kini kreativitas para perempuan terpacu seiring dengan perkembangan zaman dimana perempuan mampu mengolah bahan-bahan baku menjadi barang bernilai rupiah.

Diantara kreativitas para perempuan di Desa Belo adalah menghasilkan produk-produk yang kini sedang trend di masyarakat yang meliputi makanan, produk pakaian, obatobatan, dan lain-lain. Jikalau dahulu makanan yang dibuat adalah makanan standar sebatas lauk yang hanya dimasak untuk anggota keluarga di rumah, tenunan sarung yang pasarannya hanya di desa setempat. Tetapi kini, berbagai macam inovasi makanan maupun pakaian diproduksi dalam bentuk yang unik mengikuti selera masyarakat saat ini.

Di era milenial ini, oleh masyarakat segala bentuk bahan baku disulap menjadi sesuatu yang menarik, mampu berdaya saing dengan competitor lain serta bernilai bisnis. Program pemberdayaan BUMDes Desa Belo didominasi oleh perempuan, dimana dana yang dikucur ke masyarakat menjadi modal yang diolah untuk sebuah produk makanan atau bahan pakaian yang inovatif sehingga bernilai finansial seperti olahan bandeng presto yang memiliki kelebihan waktu penyimpanan yang cukup lama dari olahan jenis lain, cemilan krupuk dari beras, obat-obat herbal seperti bubuk kunyit temulawak untuk diseduh seperti teh atau menjadi obat tradisional ala Bima. Adapun hasil olahan tersebut akan dipasarkan oleh koperasi yang dimiliki BUMDes Desa Belo untuk konsumen yang berasal dari berbagai daerah. Selain itu, BUMDes Desa Belo bekerjasama dengan instansi pemerintah daerah agar kebutuhan kain tenun atau produk olahan makanan untuk kebutuhan acara-acara atau pertemuan dinas agar membeli pada koperasi BUMDes Desa Belo meski tidak pada semua waktu. 
Menurut pengakuan dari ketua BUMDes Desa Belo, bahwa kesempatan pemberdayaan sengaja diberikan secara dominasi kepada perempuan dengan tujuan untuk mendukung ketahanan keluarga. Dengan adanya program BUMDes merupakan wadah bagi para perempuan sebagai jalan mengakses keterampilan kepada dunia luar. Bila sebelumnya kondisi ekonomi keluarga hanya bergantung kepada kaum bapak/lakilaki sehingga tidak sedikit konflik yang terjadi dalam rumah tangga disebabkan oleh factor ekonomi. Tetapi kini dengan hadirnya BUMDes, maka perekonomian keluarga terbantu oleh penghasilan para perempuan (ibu-ibu) dengan menjual produk olahan makanan, obat-obatan herbal maupun kain tenun. Hal ini senada dengan keinginan semua pihak yang menginginkan bahwa pemberdayaan perempuan sebagai cara strategis untuk meningkatkan potensi perempuan dan meningkatkan peran perempuan baik di domain publik maupun domestik.

Begitu pula dengan yang dituturkan oleh Kepala Desa Belo yang dalam hal ini sangat mendukung program BUMDes dengan mengambil keputusan membentuk kembali kepengurusan BUMDes dan mengucurkan dana yang cukup besar untuk masyarakat terutama perempuan. Alasan kucuran dana yang lebih besar dari tahun sebelumnya adalah untuk meningkatkan progress para perempuan di Desa Belo untuk membangun ekonomi kreatif keluarga lewat program BUMDes. Karena hambatan dalam menyalurkan kreativitas tersebut hanya pada modal semata. Sehingga Pemerintah Desa memberikan akses kepada para perempuan Desa Belo untuk mengeksplorasi segala kemampuan untuk membantu ekonomi keluarga yang pada akhirnya membantu ketahanan keluarga dari sisi ekonomi.

Pemberdayaan perempuan yang dicita-citakan tercapai dengan maksimal, sehingga pemberdayaan perempuan bukan sebatas wacana semata melainkan terimplementasi dengan wujud nyata atas kerjasama pemerintah desa dengan masyarakat 
setempat. Dengan kehadiran program BUMDes di Desa Belo menciptakan hilangnya kesenjangan social ekonomi antara lakilaki dan perempuan. 


\section{Simpulan}

Pemberdayaan perempuan pada program BUMDes Desa Belo bukan hanya pada tataran wacana, tetapi lebih kepada implementasi nyata. Pemberdayaan yang seharusnya merata baik laki-laki maupun perempuan pada program BUMDes Desa Belo terlihat berbeda. Hal ini ditunjukkan dengan dominasi perempuan yang diberi ruang dan kesempatan yang lebih banyak oleh pihak BUMDes maupun pemerintah desa untuk mencapai tujuan mempertahankan Ketahanan Pangan Keluarga dari segi ekonomi.

Dengan adanya program BUMDes di Desa Belo, kaum perempuan mengeksplorasi kreativitas dengan mengolah bahan baku menjadi olahan bernilai bisnis seperti makanan atau bahan pakaian. Sebagai contoh pengolahan bandeng menjadi Bandeng Presto yang memiliki waktu penyimpanan yang lebih lama bila dibandingkan dengan olahan bentuk lain seperti bandeng bakar, bandeng goring atau bandeng palumara. Selain itu, kain tenun yang selama ini hanya dipasarkan pada lingkungan setempat, kini bisa dipasarkan di daerah luar atau dinas-dinas setempat sehingga nilai jualnya lebih tinggi

Dengan melihat implementasi dari kegiatan program BUMDes Desa Belo menunjukkan bahwa perempuan sangat diperhitungkan dalam aspek pembangunan ekonomi keluarga sehingga membantu pemerintah untuk meminimalisir penyediaan lapangan pekerjaan yang sifatnya formal. Dalam pengertian bahwa pemberdayaan perempuan menjadi prioritas utama bagi masyarakat maupun pemerintah agar perempuan tidak melulu bergantung pada laki-laki serta ditujukan untuk membantu ekonomi keluarga dengan skill para laki-laki yang minim dalam perkembangan iptek masa kini.

Sangaji Jurnal Pemikiran Syariah dan Hukum 


\section{Daftar Pustaka}

Ahdiah, Indah, "Peran-Peran Perempuan Dalam Mayarakat" Jurnal Academica FISIP Untad Vol.05 Nomor 02 Oktober 2013

Arafat, Muhammad Yasser, 2018, “Badan Usaha Milik Desa Dan Pemberdayaan Ekonomi Masyarakat Desa (Studi Pada BUMDes Tirta Mandiri Desa Ponggok Kecamatan Polanharjo Kabupaten Klaten)" Skripsi Tidak Terbit

Fajarwati, Yeni, 2016, “Implementasi Program Badan Usaha Milik

Desa (BUMDes) di Desa Pagedangan Kecamatan Pagedangan Kabupaten Tangerang", Skripsi Tidak Terbit.

Ismiati, Saptosi, 2020, Kekerasan Dalam Rumah Tangga (KDRT) dan Hak Asasi Manusia (HAM) (Sebuah kajian Yuridis), Yogyakarta: Deepublish Publisher.

Kurniawan, Ade Eka, 2015, "Peranan Badan Usaha Milik Desa (BUMDes) Dalam Peningkatan Pendapatan Asli Desa", Skripsi Tidak Terbit

Nugroho. 2008. Gender dan Administrasi Publik Studi tentang

Kualitas Kesetaraan dalam Administrasi Publik Indonesia

Pasca Reformasi 1998-2002. Yogyakarta: Pustaka Pelajar

Prijono, Onny S. dan A.M.W. Pranarka, Pemberdayaan, Konsep, Kebijakan dan Implementasi, Jakarta: CSIS

Zakiyah. 2010. Pemberdayaan Perempuan oleh Lajnah Wanita.

Jurnal Pengkajian Masalah Sosial Keagamaan, No.XVII. Suharto, Edi. 2003. Pembangunan Kebijakan dan Kesejahteraan Sosial. Bandung: Mizan

Undang-undang Republik Indonesia nomor 6 Tahun 2014 Tentang Desa 